\title{
Appropriate Assistive Technology for Developing Countries
}

Toro-Hernández, María Luisa; Kankipati, Padmaja; Goldberg, Mary; Contepomi, Silvana; Tsukimoto, Denise Rodrigues; Bray, Nathan

\section{Physical Medicine and Rehabilitation Clinics of North America}

DOI:

10.1016/j.pmr.2019.07.008

Published: 01/11/2019

Peer reviewed version

Cyswllt i'r cyhoeddiad / Link to publication

Dyfyniad o'r fersiwn a gyhoeddwyd / Citation for published version (APA):

Toro-Hernández, M. L., Kankipati, P., Goldberg, M., Contepomi, S., Tsukimoto, D. R., \& Bray, N. (2019). Appropriate Assistive Technology for Developing Countries. Physical Medicine and Rehabilitation Clinics of North America, 30(4), 847 - 865.

https://doi.org/10.1016/.jpmr.2019.07.008

Hawliau Cyffredinol / General rights

Copyright and moral rights for the publications made accessible in the public portal are retained by the authors and/or other copyright owners and it is a condition of accessing publications that users recognise and abide by the legal requirements associated with these rights.

- Users may download and print one copy of any publication from the public portal for the purpose of private study or research.

- You may not further distribute the material or use it for any profit-making activity or commercial gain

- You may freely distribute the URL identifying the publication in the public portal ?

Take down policy

If you believe that this document breaches copyright please contact us providing details, and we will remove access to the work immediately and investigate your claim. 


\section{Appropriate Assistive Technology for Developing Countries}

María Luisa Toro-Hernández ${ }^{1,}$, PhD; Padmaja Kankipati², PhD; Mary Goldberg ${ }^{3}$, PhD, Silvana

Contepomi4 ${ }^{4}$ PT, Denise Rodrigues Tsukimoto5 ${ }^{5}$ OT, Nathan Bray ${ }^{6}, \mathrm{PhD}$

1School of Physiotherapy, Universidad CES, mhtoro@ces.edu.co, Calle 10A \#22-04, Medellín, Colombia

2Specialized Mobility Operations \& Innovation, padmaja.kankipati@smoi.org, 804, Brigade Rubix, No. 20, HMT Main Road, Yeshwanthpura, Bangalore, 560022 India

${ }^{3}$ International Society of Wheelchair Professionals, Department of Rehabilitation Science and Technology and Human Engineering Research Laboratories, University of Pittsburgh, mgoldberg@pitt.edu, 6425 Penn Ave Suite 400, Pittsburgh, PA, 15206, United States

4 Asociación Argentina de Tecnología Asistiva (AATA), silvanacontepomi@gmail.com, Francia 3166, San Isidro, 1642, Argentina.

${ }^{5}$ Physical Medicine and Rehabilitation Institute (IMREA), Hospital das Clinicas, University of Sao Paulo, denise.t@hc.fm.usp.br, IMREA Rua Diderot, 43 CEP: 04116030 Sao Paulo- SP Brazil

${ }^{6}$ School of Health Sciences, Bangor University, Bangor, Gwynedd, LL57 2EF, n.bray@bangor.ac.uk, Bangor, United Kingdom.

${ }^{*}$ Corresponding author

Disclosure statement: all authors disclose no financial conflict of interest.

\section{Synopsis}

Access to appropriate and affordable assistive technology is a human rights, a public health, and a development priority. This chapter elaborates on these aspects and illustrates the various opportunities and barriers to achieving equitable access to assistive technology through four specific country snapshots. In Brazil, mobility aids are provided through the universal health coverage in rehabilitation reference centers in urban areas. A community-based rehabilitation pilot project in Argentina demonstrates how to reach to an excluded indigenous community. A rapidly developing national legal framework in Colombia with imminent implementation challenges is showcased, as well as a technology transfer model in India. 
Key words: Assistive technology, access, evidence-based, human rights, policy, service provision, workforce.

\section{Key Points}

- For many people with decreased functioning, assistive technology is required to participate as independently as possible in the activities that one values.

- It is a human right to provide proximate access to appropriate assistive technology service provision for those who need it.

- Coordinated efforts to advance policy, provision, products, and personnel based on up-todate and reliable understanding of the population's needs are urgent in the developing world.

- Deep understanding of the nuances and particularities of each context are a prerequisite to progress.

- International cooperation and technical assistance are needed to reach the most vulnerable as fast as possible.

\section{Introduction}

The International Classification of Functioning, Disability, and Health defines the spectrum between functioning and disability as the result of a complex interaction between an individual with a health condition and his/her context that may result in activity limitations and participation restrictions ${ }^{1}$. The rapid rise in ageing population and the increased prevalence of non-communicable diseases, translates to a rise in the number of individuals living with long term impaired functioning ${ }^{1,2}$. Assistive technology (AT) is an umbrella term that describes products and services that enhance individuals' functioning and participation; including systems, services, products, devices, equipment, and software 134. Therefore, AT promotes independence both in people with disabilities across their lifespan ${ }^{5}$ and older adults ${ }^{6}$. Eighty percent of people with disabilities live in the developing world ${ }^{7}$ and the World Health Organization (WHO) estimates approximately 1 in 10 individuals that need AT, have access to it ${ }^{8}$. Women, children, individuals with multiple impairments (e.g. people who are deafblind ${ }^{9}$ ) and people in emergency and disaster situations are at higher risk of exclusion ${ }^{10,11,12}$. The adoption of the United Nations Convention on the Rights of Persons with Disabilities (CRPD) in 2006 recognizes access to appropriate and affordable AT as a human right ${ }^{13}$ resulting in increased awareness and 
advocacy worldwide ${ }^{14,5,15}$. The CRPD has been ratified by 175 United Nations Member States, who are thus obligated to ensure affordable AT is available to all individuals in need ${ }^{8}$. Governments therefore have an obligation to coordinate high volume AT procurement and import tax waivers to reduce costs subsequently improving AT coverage. Nevertheless, their remain persistent challenges to the the fulfillment of commitment to the ageing and disability community ensuring equitable access to appropriate AT ${ }^{8}$. The Sustainable Development Goals call for inclusive actions to leave no one behind and design poverty alleviation and development programmes inclusive to people with disabilities and older adults ${ }^{16,15,17}$. Hence AT can be described both as a mediator and moderator of sustainable development ${ }^{15,17}$.

Access is a complex concept that involves availability, physical accessibility, adequate supply, affordability, and acceptability ${ }^{18}$. Although AT products are essential, as illustrated in figure 1 , successful access depends on integrated efforts related to end users (the 'people'), provision, personnel, and policy, deemed the five 'P's by the World Health Organization's Global Cooperation on Assistive Technology (WHO GATE) ${ }^{19,20}$. These 5Ps are unique to each context ${ }^{21}$.

This chapter will briefly detail 1) AT types and progress towards making them globally available, 2) AT challenges in developing countries, including cost-effectiveness of AT, 3) select country snapshots demonstrating AT systems in practice, and 4) opportunities in improving access to appropriate AT and service provision.

\section{Types of assistive technology}

To assist governments the WHO published the Assistive Priority List (APL) that includes 50 products, developed via a global delphi study, across a variety of AT types ${ }^{6}$. Governments are urged to adapt and adopt the APL according to their national needs (people) ${ }^{6}$. However this may be overwhelming for governments; the ISO AT classification system (Table 1) could be a useful guide.

Table 1. Assistive Technology products classification according to ISO 9999:2016 [Adapted from the European Search Engine on Assistive Technology]

ISO 9999:2016 product class

Product examples (not comprehensive but intended to illustrate the vast range, one 


\begin{tabular}{|l|l|}
\hline & product may belong to more than one class) \\
\hline $\begin{array}{l}\text { For measuring, supporting, training or replacing } \\
\text { body functions }\end{array}$ & $\begin{array}{l}\text { Pressure relief wheelchair cushion (for tissue } \\
\text { integrity) }\end{array}$ \\
\hline For education and for training in skills & $\begin{array}{l}\text { Mobile application to train in everyday activities } \\
\text { Paint brush with thick handle to train in painting } \\
\text { skills }\end{array}$ \\
\hline $\begin{array}{l}\text { Attached to the body for supporting } \\
\text { neuromusculoskeletal or movement related } \\
\text { functions and replacing anatomical structures }\end{array}$ & $\begin{array}{l}\text { Below-knee prosthesis } \\
\text { Spine orthosis }\end{array}$ \\
\hline $\begin{array}{l}\text { For self-care activities and participation in self } \\
\text { care }\end{array}$ & $\begin{array}{l}\text { Kids protective cap } \\
\text { One-handed buttoning devices and fasteners }\end{array}$ \\
\hline $\begin{array}{l}\text { For activities and participation relating to } \\
\text { personal mobility and transportation }\end{array}$ & $\begin{array}{l}\text { Van that can be driven from a power wheelchair } \\
\text { Elbow crutches } \\
\text { White cane }\end{array}$ \\
\hline $\begin{array}{l}\text { For domestic activities and participation in } \\
\text { domestic life }\end{array}$ & $\begin{array}{l}\text { Easy grip garden fork } \\
\text { Fixed food cutting board }\end{array}$ \\
\hline $\begin{array}{l}\text { Furnishings, fixtures and other assistive } \\
\text { products for supporting activities in indoor and } \\
\text { outdoor human-made environments }\end{array}$ & $\begin{array}{l}\text { Chair with special mechanism to assist the } \\
\text { person to stand } \\
\text { Kids floor seats }\end{array}$ \\
\hline $\begin{array}{l}\text { For communication and information } \\
\text { management }\end{array}$ & $\begin{array}{l}\text { Magnifier lens } \\
\text { Face-to-face communication software } \\
\text { Computer joystick }\end{array}$ \\
\hline $\begin{array}{l}\text { For controlling, carrying, moving and handling } \\
\text { objects and devices }\end{array}$ & $\begin{array}{l}\text { Reacher } \\
\text { Small table on wheels }\end{array}$ \\
\hline $\begin{array}{l}\text { For controlling, adapting or measuring elements } \\
\text { of physical environments }\end{array}$ & $\begin{array}{l}\text { Noise reduction board } \\
\text { Barometer }\end{array}$ \\
\hline $\begin{array}{l}\text { For work activities and participation in } \\
\text { employment }\end{array}$ & $\begin{array}{l}\text { Workplace mat for reducing vibration } \\
\text { Height adjustable work bench }\end{array}$ \\
\hline For recreation and leisure & $\begin{array}{l}\text { Switch-activated toys } \\
\text { Blind-soccer ball }\end{array}$ \\
\hline
\end{tabular}

In the absence of adequate access to appropriate AT, Do-it-yourself (DIY) initiatives are becoming more popular, with the democratization of information and tools (e.g 3D-printing). The risk of DIY AT is the possibility of inappropriate products reaching end users ${ }^{22}$.

\section{Challenges in assistive technology in developing countries}


Challenges including limited policy governing supply and provision, an insufficient workforce, limited training capacity, and limited product supply and enforced standards accumulate to create a difficult environment to ensure appropriate AT is provided to users, especially in developing countries ${ }^{23-26}$.

International human rights legislation can provide a helpful framework, but national examples of legislation and policy governing AT are limited. For example, South Africa Guidelines for AT Service Standardization ${ }^{27}$, Chile 'Funding orientations for AT' $2018^{28}$, and Nordic Countries Provision of AT $2007^{29}$ provide an upper-middle income, and high-income examples, respectively, of national level guidelines. Papua New Guinea offers Draft Guidelines from $2016^{30}$ as a lower middle income example. The global landscape is not as promising. Without mandated policies through national legislation, providers are unlikely to pursue and maintain certification, and if governments do finance AT, they are unlikely to be aware of or adhere to product standards.

Without governing policy, training is unlikely to be required for AT providers. Inadequate training of rehabilitation or community healthcare providers (CHP), who are often the first point of people contact $^{31}$, can result in inappropriate provision, which have negative impacts on quality of life, health, safety, and other human rights ${ }^{32-36}$. Trained service providers (personnel) have the potential to reduce AT users' prevalence of secondary health conditions and may contribute to reducing disparities ${ }^{32}$.

\section{Building capacity goes hand in hand with the integration of these services into existing healthcare programs for ensuring equitable access to appropriate AT 3738 .}

In addition to policy, training, and workforce concerns, products may also be limited and those that are available may not meet standards ${ }^{19}$. Two key barriers to ensuring universal AT provision are cost and availability - the low production levels of AT within many developing countries leads to increased scarcity, subsequently the specialised nature of AT interventions leads to small markets and thus higher costs ${ }^{39}$. Few countries govern product supply;simply making the technology available to a population is insufficient, as inappropriate products can still be delivered to the user ${ }^{19}$.

It is evident that the relative cost-effectiveness of most AT in developing nations is unclear, predominantly due to an almost non-existent evidence base. To understand the efficiency of different 
AT equipment and services, it is important to not only understand their cost but also the subsequent benefits they provide for AT users. By exploring how best to measure the cost and benefits of AT, health economists can help to determine which technologies and devices offer the most cost-effective method of improving the quality of life and health of people with impairments. Furthermore, by assessing a range of comparable AT, incremental costs and benefits of competing alternatives can be examined. Thus decisions about provision can be guided by incremental cost-effectiveness evidence. In developing countries it is imperative that AT are low-cost, durable and simple to produce/repair locally. However, the relationship between cost and user outcomes is equally important, as the relative value for money of AT can only be determined by examining the cost per unit of effect. Furthermore, the perspective of such analysis needs to be explicit, as cost-effectiveness estimates are likely to vary depending on whether a government, charity or individual is expected to pay for their own AT. Methods of economic evaluation need to be imbedded in future research in this context, and seen as an integral part of the evaluation of AT interventions and services across the world. In order to examine the relationship between costs and outcomes, health economists commonly undertake economic evaluations. Health economics and the economic evaluation of health technologies has becoming increasingly influential in the financing and analysis of healthcare across the world. One of the predominant approaches to economic evaluation is cost-effectiveness analysis (CEA), which compares alternative methods of achieving a predetermined outcome, for example additional life years. CEA directly examines the relationship between costs and effects (i.e. benefits) for a specified intervention and comparator ${ }^{40}$. The intervention which incurs the least cost and highest benefit (or equal benefit) is determined the most cost-effective intervention ${ }^{41}$. An incremental costeffectiveness ratio (ICER) may be calculated to compare relative costs and incremental benefits of differing but comparative interventions. CEA relies on a single outcome measure, as cost cannot be attributed to two separate outcomes or when outcomes are mutually exclusive (i.e. extended life but decreased quality of life $)^{41}$. Direct comparison between the value of costs and effects is not possible 40,42 .

To date the application of methods of economic evaluation to AT has been limited, particularly in low and middle income countries. This is partially due to the difficulties of applying traditional methods of economic evaluation in the context of AT provision, where outcomes are often less explicitly defined compared to pharmaceutical and surgical interventions. Although AT costs are frequently reported in 
this context ${ }^{43}$, specific cost-effectiveness analyses are few and far between. The evidence available in the developing world on AT is mostly focused on mobility and vision devices and more than half of the studies are observational designs ${ }^{44}$.

The way the various challenges manifest in practice is context-dependent as revealed in the country snapshots below.

\section{Country snapshots}

As mentioned previously, assistive technology products are essential but not sufficient to guarantee the right to appropriate $A T^{19,20}$. This chapter presents brief country snapshots to help the reader grasp the complexities, challenges, and opportunities that are entangled in each of the contexts. These snapshots are not representative of the developing world as a whole, as each context is unique.

\section{Argentina: community empowerment to provide assistive technology to the most vulnerable}

Argentina is an emerging economy, similar to most of the countries in the region and shares corruption scandals that make poverty and violence evident. Currently, $27.3 \%$ of its population live in poverty ${ }^{45}$ and disability is prevalent in $10.2 \%$ of the population ${ }^{46}$. Since 2001 , the Ministry of Health manages the unified national disability registry which provides the disability certificate that includes the cause, level, and rehabilitation services ${ }^{47}$. This law allows for the provision of assistive technology products, but most remote and poor places lack appropriate processes to guarantee the rights of people with disabilities.

An example of a vulnerable group in Argentina is the indigenous group Wichi that lives in the region Banda Sur del Chaco Salteño. This region accounts for a higher rate of $t$ childhood malnourishment and poverty, than the national average ${ }^{48}$. A health community strengthening program led by social workers identified several cases of children with mobility impairments laying on the floor all day due to lack of appropriate AT. To promote the rights of these children, by providing access to appropriate $\mathrm{AT}^{13}$, a pilot project based on the WHO Community-Based Rehabilitation ${ }^{49}$ (CBR) and the 8-stepsWheelchair provision ${ }^{33}$ started in 2016 . Two social workers and one physical therapist (trained in the WHO Wheelchair Service Provision Package ${ }^{50}$ ) designed and carried out the pilot program (figure 2).

\section{Lessons learned:}


- 21 children have received an appropriate wheelchair and training on its use and on postural care (Figure 3).

- An increase in the number of cases of children requiring wheelchairs may indicate families having children at home without any community involvement.

- Fulfilment of the initial project goal, i.e. access to appropriate AT, led to increased community participation that resulted in new needs became evident (e.g. ramps, alternative communication solutions, toy adaptation etc.). Although, the CBR project focussed on the AT element of the health component, it contributed to building awareness about promotion of inclusive development strategies in this community.

Steps forward: The program will train several health agents that have been helping with users' assessment and product prescription. The government has started to offer more training opportunities in CBR that promote inclusion.

\section{Brazil: public health commitment to foster progress in rehabilitation}

The 2000 Demographic Census reported that $14.5 \%$ of the Brazilian population had a disability which rose to $23.9 \%$ in 2010 . There is an increased demand for rehabilitation services and technologies ${ }^{51}$. Strengthening the provision of rehabilitation services and ensuring their proper funding is critical to guarantee that rehabilitation is available and affordable to those who need it ${ }^{52}$. Public health in Brazil has two distinct phases, and the creation of the Unified Health System (SUS for its name in Portuguese) is the watershed of these phases. Prior to the creation of the SUS in 1988, health was restricted to a portion of the population that had social insurance. Public health actions were of a preventive and community nature, with few health care exceptions focused on specific diseases or population groups, and assistance to people with disabilities was performed by philanthropic institutions ${ }^{53,54}$. In the 1988 Constitution, health was recognized as every citizen's right that must be guaranteed by the government ${ }^{53,54}$. Efforts have been made to increase the quality, equity and economic accessibility of services ${ }^{52}$. The financing of SUS by the federal, state and municipal governments should promote the collection and transfer of necessary resources in order to guarantee the universality and completeness of the system. Underfunding of SUS results in difficulties in meeting population demands and providing quality services to the population. 
Even in the face of these difficulties, through the commitment of professionals and managers in the area of public health and the participation of various stakeholders; exemplary actions and quality services have been developed, albeit with greater concentration in the urban central areas, including: - Development of national guidelines for the care of people with disabilities based on scientific evidence to guide rehabilitation actions.

- Evaluation and delivery of quality orthoses, prostheses, and mobility aids through the SUS in rehabilitation reference centers.

- Development of research projects and introduction of new technologies through academic studies and research / innovation promotion agencies.

- The formation of a state level rehabilitation network in São Paulo, to provide health care coverage and educational and research actions; including a Mobile Rehabilitation Unit.

Rehabilitation research and development efforts within the public health system, have resulted in: a. Robotic technology for functional improvement of the limbs. b. Application of virtual reality and biofeedback by surface electromyography. c. Evaluations and therapies with neuromodulation. $d$. Application of functional electrical stimulation, shock waves, and other physical treatment agents. Numerous government assisted efforts conducted have resulted in the development and use of: digital accessibility and augmentative communication resources; vocational courses, therapeutic workshops and inclusion activities; and a Paralympic Center, to name a few. Continuing education initiatives for rehabilitation professionals ensure they remain up-to-date with new developments resulting in improved services.

Steps forward:Two types of actions are needed for successful implementation of rehabilitation technology.

- People with disabilities, caregivers and undergraduate and postgraduate students, and the community as a whole need to be trained on appropriate AT usage (Figure 4).

- All stakeholders (end users, government ministries, social institutions, industry etc.), need to coordinate for effective implementation. 


\section{Colombia: significant policy advances, need for greater coordination and implementation.}

Colombia has a population of 45,5 million ${ }^{55}$, is an upper-middle income economy, and has one of the largest inequalities in the region $-26,9 \%$ of its population live under the poverty line ${ }^{56}$. It has more than 60 years of internal conflict that has resulted in more than 7,9 million people internally displaced and more than 11,000 landmine victims ${ }^{57,58}$. Preliminary data from the 2018 population census report that $7,2 \%$ live with a disability ${ }^{59}$.

The legal framework in Colombia has a rights-based approach, it has a young constitution (1991) that prohibits discrimination based on race, gender, ethnicity, religion, and disability and mandates the government to protect these vulnerable groups ${ }^{60}$. A peculiarity of the context is that for a law to be enforced - after enacted by the congress - it must be ruled by the executive branch, posing significant bureaucratic barriers towards the implementation of new enacted laws. The country has made significant strides towards Universal Health Coverage (UHC), $94,36 \%$ of the country's population is covered by a mandatory health care plan ${ }^{61}$; but, effective access to services remains a challenge and constantly requires legal appeal62. There are several policies and programs from before the CRPD that have impacted access to AT:

- Since 2001 the Relay Center provides at no cost online video-to-voice relay calls, online Colombian Sign Language (CSL) interpretation, and promotes CSL ${ }^{63}$.

- The National Disability System (2007), coordinated by the Interior Ministry, was created to articulate work between the public sector and civil society organizations to advocate and inform public policy and its implementation at the municipal, departmental, and national levels ${ }^{64}$.

- The mandatory health care plan provided access to hearing aids, external lenses ( out-ofpocket charges for the frame, filters and protections), and prosthetics and orthotics since 200765 including assessment and fitting services. Wheelchairs, cushions, and therapeutic footwear were explicitly excluded from the plan ${ }^{65}$.

The country signed (2009) and ratified (2011) the CRPD which was later enacted in the Disability law (2013) and a National Disability Public Policy ${ }^{66}$. After the ratification of the CRPD, the following changes have been made:

- The Ministry of Health $(\mathrm{MoH})$ shall define, validate, implement, and evaluate the national comprehensive rehabilitation model ${ }^{67}$. This has the potential of creating an umbrella strategy that coordinates all the advances in AT. 
- The National CBR guidelines published in 2014 , promote coordination between the $\mathrm{MoH}$ and community agents (including people with disabilities) to facilitate access and maintenance of AT ${ }^{68}$. Little is known about the implementation ${ }^{69}$.

- The Ministry of Information and Telecommunications acquired a national license (2013), for the screen-reader JAWS and the screen magnifier MAGIC allowing more than 570 thousand free downloads across the country by December, $2017^{70,71}$.

- Highlights of a new healthcare law (2015) aimed to improve equitable access to health ${ }^{72,73}$

- Prosthetic and orthotic products and personnel need to comply to regulatory standards and licensing ${ }^{74,75}$.

- Although speech therapy is covered, there is no mention of Augmentative and Alternative Communication services and devices ${ }^{72}$.

- The $\mathrm{MoH}$ is mandated to provide funding to support Assistive Technology Banks (ATB) designed to provide products that are excluded from the mandatory health plan to the poorest citizens (few being operational) ${ }^{74}$.

- MoH indicated that Braille boards should be provided by the Ministry of Education and incontinence pads by municipal or provincial local authorities, without specifying which entity ${ }^{76}$

- In 2015, the Military forces enacted AT guidelines - including requirements on personnel, provision, and products ${ }^{77}$.

- Since 2016, the National Television Authority mandates the implementation of closed caption in national, provincial, and local public television ${ }^{78}$.

- In 2017, the Ministry of Education (MoE) enacted the decree for students with disabilities to have an individual reasonable accommodation plan (inclusive of AT), with the national government providing funds ${ }^{79}$ and the local education authorities responsible for implementation. ${ }^{79} 80$.

- The National Institute for the Blind (MoE) launched the free virtual library for people with visual impairment allowing access to audio books and accessible digital content via mobile and web browsing ${ }^{81}$. 
- The Ministry of Labor passed the public employment decree (2017) that mandates local, provincial, and national government to reserve a quota for employees with disability. Each public entity would be in charge of the needed reasonable accommodations ${ }^{82}$.

Figure 5 synthesizes the national policy advances made and the challenges towards local implementation. Poor policy implementation is evident as people with disabilities still face disproportionate low education, employment, and health outcomes ${ }^{83}$. Public implementation efforts still fail to reach the most vulnerable, international NGOs (e.g. International Committee of the Red Cross, Humanity for Inclusion, and World Vision) still play a role in providing access to prosthetics, orthotics, and wheelchairs to conflict survivors and people in rural communities $84,85,86$. The civil society shadow report to the UN states highlights a lack of sufficient trained personnel related to rehabilitation, no care pathways, and those in rural areas have no access to professionals and services they need ${ }^{87,88}$.

Steps forward: The National Disability System poses a great opportunity to coordinate and unite the currently fragmented policy, infrastructure, and services with the goal of ensuring a widespread availability of appropriate AT as close as possible to their living location. It is urgent to conduct coordinated and financed capacity-building efforts on the personnel, provision, and product aspects to implement the legal framework advances. This could be designed with technical assistance from national experts (e.g. Ministries of Defense) and the $\mathrm{WHO}^{89}$ to achieve the CRPD mandate with regards to AT.

\section{India: international cooperation and collaboration supporting sustainable innovation}

The Disabilities Act (2016) is the most recent comprehensive law in terms of non-discrimination against persons with disabilities and obligates the corporate sector to ensure equal employment opportunity is provided. However little has been mentioned in terms of access to AT apart from the onus of provision lies as an obligation of the private employer. The perception of disability in India has long been held as a social welfare concern. The Disability Act (2016) is indicative of the changing paradigm from a charitable model to that of a human rights issue.

One of the largest government financial aid programs for procuring AT is through the Assistance to Disabled Persons for Purchasing/Fitting of aids/Appliances (ADIP) scheme. The biggest agency 
implementing the ADIP scheme is the Artificial Limbs Manufacturing Corporation of India (ALIMCO), a public sector undertaking. ALIMCO provides a range of AT products (e.g. crutches, wheelchair, walking cane, braille slate, hearing aids etc.). Products are provided through various fitting centers and donations through camps run in the rural and semi urban areas of India, thereby establishing it as the largest national distributor of AT. Recent developments include new products and capacity building efforts for ALIMCO staff., which will positively impact product and service quality ${ }^{90}$. Figure 6 illustrates this technology transfer scheme.

An example that showcases a successful collaborative effort of a sustainable innovation is the ReMotion Knee, which retails at approximately 80 USD. Now led by D-Rev, a non-profit company, ReMotion Knee is currently being fitted in the Jaipur foot clinic and the company is currently establishing partnerships with prosthetics providers globally, expanding access to people with disabilities in India and beyond ${ }^{91}$.

Steps forward: Although the recent legislation is a step in the right direction to be more compliant with the CRPD, national standards for products and services need to be adopted according to global standards to ensure quality of services and products improve. Additionally successful implementation of policies require a collective approach from all stakeholders.

\section{Opportunities in the road ahead}

As evidenced in the snapshots, countries are pursuing and experiencing unique pathways in ensuring appropriate AT products and service provision for all. In order to address any of the challenges presented, awareness raising strategies must be implemented: the benefits of assistive technology and appropriate service provision should be known by different stakeholders that work with people with activity limitations across their lifespan - people with disabilities and their organizations (DPOs), older adults, rehabilitation professionals, gerontologists, psychologists, educators, health agents, community health care workers, engineers, and designers. In addition to WHO open-source resources, there are other freely available knowledge and product platforms that are in several

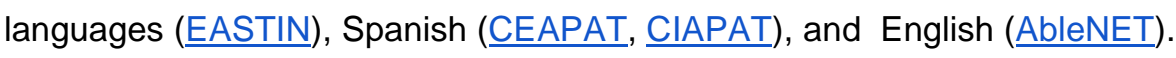

Next, political will and a high level of engagement are necessary. Tajikistan, with the polio outbreak in 2010, was able to establish a national rehabilitation framework - including AT - in less than 10 years ${ }^{89}$. 
In addition to the high level commitment, they were able to succeed with technical assistance from WHO and international development funds from the US ${ }^{89}$. WHO GATE has invested in identifying tools and helpful case studies related to AT policy ${ }^{20}$ and the International Society of Wheelchair Professionals (ISWP) has developed a policy toolkit for stakeholders who are influencing national policy decisions related to wheelchairs ${ }^{92}$.

Related to personnel capacity building, WHO has published a series of open-source Wheelchair Service Training Packages in multiple languages to assist nations in fulfilling the CRPD mandate of supporting providers' training and help to bridge the gap in training disparity across developing countries $^{33,50}$. In developing countries, standard in-person trainings may be inaccessible, but in some cases, online learning has addressed various challenges of in-person training such as limited access and high $\operatorname{cost}^{93,94}$. Building from this success, WHO GATE is developing a series of online, opensource AT modules that focus on AT represented in the WHO Priority Assistive Technologies list ${ }^{95}$. Complementary assessments, certification, and accreditation that validate AT competency and capacity such as those offered by ISWP96, ISPO ${ }^{97}$ and CECOPS 98 may institute quality control throughout the rehabilitation system..

Related to products, market shaping (interventions that aim to reduce long-term demand and supply imbalances and reach a sustainable equilibrium) has the potential to address breakdowns in the healthcare market and support better health outcomes for people in developing countries ${ }^{99}$. USAID recommends five simple steps including observing market shortcomings, diagnosing root causes, assessing market shaping options, implementing customized interventions, and measuring results ${ }^{100}$. USAID's ATScale: A Global Partnership for Assistive Technology project, has taken a deeper dive into rehabilitation technology specifically and aims to help 500 million people get the AT they need by 2030 through service delivery and market-shaping approaches; creating partnerships with the private sector to build and serve markets in the lowest-resource countries; supporting the development of country plans for greater access; and catalyzing innovation to design and introduce suitable AT where needed ${ }^{101}$. In developing countries, such as Brazil, where local production of AT has been established, the use of readily available indigenous resources facilitates low-cost AT solutions, as excessive import costs can be avoided as well as abandonment due to lack of repair components ${ }^{43}$. 
Furthermore, the mass production of AT in countries such as India has led to lower production costs and increased opportunities for international exports ${ }^{43}$. Governments should also remove or reduce import taxes on relevant materials and AT to ensure that population need for AT does not outstrip availability.

Last, robust research, monitoring and evaluation plans must be created and followed to be able to build and strengthen the evidence that is lacking and the global AT sector needs ${ }^{102}$. 
1. World Health Organization. International Classification of Functioning, Disability and Health: ICF. World Health Organization; 2001.

2. World Health Organization. World Report on Ageing and Health. World Health Organization; 2015.

3. [PDF] ISO 9999:2016. https://www.sis.se/api/document/preview/920988/.

4. World Health Organization. Global Cooperation on Assistive Technology. World Health Organization. http://www.who.int/phi/implementation/assistive_technology/phi_gate/en/. Accessed August 16, 2018.

5. Johan Borg, Rosangela Berman-Bieler, Chapal Khasnabis, Gopal Mitra, William N Myhill, and Deepti Samant Raja. Assistive Technology for Children with Disabilities: Creating Opportunities for Education, Inclusion and Participation. World Health Organization and UNICEF; 2015. https://www.unicef.org/disabilities/files/Assistive-Tech-Web.pdf.

6. World Health Organization. Priority Assistive Products List. World Health Organization; 2016.

7. World Health Organization. World Report on Disability. World Health Organization; 2011.

8. WHO | Seventy-first World Health Assembly adopts resolution on assistive technology. July 2018. http://www.who.int/phi/implementation/assistive_technology/71stWHA-adopts-resolutionon-assistive-technology/en/. Accessed August 30, 2018.

9. World Federation of the Deafblind. At Risk of Exclusion from CRPD and SDGs Implementation: Inequality and Persons with Deafblindness. World Federation of the Deafblind; 2018.

http://www.internationaldisabilityalliance.org/sites/default/files/wfdb_complete_initial_global_repo rt_september_2018.pdf.

10. Disability-inclusive Humanitarian Action | United Nations Enable. United Nations - Disability. https://www.un.org/development/desa/disabilities/issues/whs.html. Accessed October 24, 2018.

11. UNICEF. The State of the World's Children 2013: Children with Disabilities. UNICEF; 2013. https://www.unicef.org/sowc2013/files/SWCR2013_ENG_Lo_res_24_Apr_2013.pdf.

12. United Nations. Report of the Special Rapporteur on the Rights of Persons with Disabilities. United Nations; 2018. https://www.ohchr.org/Documents/lssues/Disability/A_73_161_EN.pdf.

13. United Nations. Convention on the Rights of Persons with Disabilities. 2006. http://www.un.org/disabilities/documents/convention/convoptprot-e.pdf.

14. Borg J, Larsson S, Östergren P. The right to assistive technology: for whom, for what, and by whom? Disabil Soc. 2011;26(2):151-167.

15. Tebbutt E, Brodmann R, Borg J, MacLachlan M, Khasnabis C, Horvath R. Assistive products and the Sustainable Development Goals (SDGs). Global Health. 2016;12(1):79.

16. Lena Morgon Banks SP. The Economic Costs of Exclusion and Gains of Inclusion of People with Disabilities: Evidence from Low and Middle Income Countries. International Centre for Evidence in Disability http://disabilitycentre.Ishtm.ac.uk/new-report-economic-costs-exclusion-gainsinclusion-people-disabilities/.

17. United Nations. Sustainable Development Goals. 2017. doi:10.18356/107200fd-en.

18. Gulliford M, Figueroa-Munoz J, Morgan M, Hughes D, Gibson B, Beech R, Hudson M. What does "access to health care" mean? J Health Serv Res Policy. 2002;7(3):186-188. 
19. Smith RO, Scherer MJ, Cooper R, Bell D, Hobbs DA, Pettersson C, Seymour N, Borg J, Johnson MJ, Lane JP, Sujatha S, Rao P, Obiedat QM, MacLachlan M, Bauer S. Assistive technology products: a position paper from the first global research, innovation, and education on assistive technology (GREAT) summit. Disabil Rehabil Assist Technol. 2018;13(5):473-485.

20. WHO | Global Cooperation on Assistive Technology - About us. July 2018.

http://www.who.int/phi/implementation/assistive_technology/phi_gate/en/. Accessed September 4, 2018.

21. Global Research, Innovation and Education in Assistive Technology. World Health Organization; 2017. http://apps.who.int/iris/bitstream/handle/10665/259746/WHO-EMP-IAU-2017.16eng.pdf;jsessionid=385451B25A6EA35BDDC725847B45A1DA? sequence $=1$.

22. Grott R. Will 3D Printers Make Our Profession Obsolete?|Rehabilitation Engineering \& Assistive Technology Society of North America. Rehabilitation Engineering and Assistive Technology Society of North America. https://www.resna.org/blog/will-3d-printers-make-our-professionobsolete. Published May 7, 2015. Accessed November 20, 2018.

23. [PDF]Social Panorama of Latin America 2012 - Cepal. https://www.cepal.org/publicaciones/xml/4/48454/SocialPanorama2012Docl.pdf.

24. McSweeney E, Gowran RJ. Wheelchair service provision education and training in low and lower middle income countries: a scoping review. Disabil Rehabil Assist Technol. November 2017:113.

25. Who WB. World report on disability. Geneva: WHO. 2011.

26. Banks LM, Kuper H, Polack S. Poverty and disability in low- and middle-income countries: A systematic review. PLoS One. 2017;12(12):e0189996.

27. STANDARDISATION OF PROVISION OF ASSISTIVE DEVICES IN SOUTH AFRICA: A GUIDELINE FOR USE IN THE PUBLIC SECTOR. http://dev.prizumweb.com/smart/wpcontent/uploads/2018/07/South-Africa-Guidelines-for-AT-service-standardization.pdf.

28. Tecnologias para la inclusion. http://dev.prizumweb.com/smart/wpcontent/uploads/2018/07/Chile-Orientaciones-FInanciacion-AT-2018.pdf.

29. Provision of Assistive Technology in the Nordic Countries Second Edition. http://dev.prizumweb.com/smart/wp-content/uploads/2018/07/Nordic-Countries-Provision-of-AT2007.pdf.

30. National Guidelines on the Provision of Assistive Technology in Papua New Guinea. http://dev.prizumweb.com/smart/wp-content/uploads/2018/07/Papau-New-Guinea-Draft2016.pdf.

31. Vasan A, Mabey DC, Chaudhri S, Brown Epstein H-A, Lawn SD. Support and performance improvement for primary health care workers in low- and middle-income countries: a scoping review of intervention design and methods. Health Policy Plan. 2017;32(3):437-452.

32. Visagie S, Scheffler E, Schneider M. Policy implementation in wheelchair service delivery in a rural South African setting. Afr J Disabil. 2013;2(1):63.

33. World Health Organization, WHO. Guidelines on the Provision of Manual Wheelchairs in Less Resourced Settings. World Health Organization; 2008.

34. Universal Declaration of Human Rights. http://www.un.org/en/universal-declaration-humanrights/. Published October 6, 2015. Accessed August 29, 2018.

35. Toro ML, Eke C, Pearlman J. The impact of the World Health Organization 8-steps in wheelchair service provision in wheelchair users in a less resourced setting: a cohort study in Indonesia.

BMC Health Serv Res. 2016;16(1):26. 
36. Borg J, Lindström A, Larsson S. Assistive technology in developing countries: national and international responsibilities to implement the Convention on the Rights of Persons with Disabilities. Lancet. 2009;374(9704):1863-1865.

37. Tangcharoensathien V, Witthayapipopsakul W, Viriyathorn S, Patcharanarumol W. Improving access to assistive technologies: challenges and solutions in low- and middle-income countries. WHO South East Asia J Public Health. 2018;7(2):84-89.

38. Boisselle AK, Grajo LC. They Said: A Global Perspective on Access to Assistive Technology. The Open Journal of Occupational Therapy. 2018;6(3). doi:10.15453/2168-6408.1541.

39. Li W, Sellers C. Improving assistive technology economics for people with disabilities: Harnessing the voluntary and education sectors. In: 2009 IEEE Toronto International Conference Science and Technology for Humanity (TIC-STH). ; 2009. doi:10.1109/tic-sth.2009.5444391.

40. Neumann PJ, Goldie SJ, Weinstein MC. Preference-based measures in economic evaluation in health care. Annu Rev Public Health. 2000;21:587-611.

41. Brazier J. Measuring and Valuing Health Benefits for Economic Evaluation. Oxford University Press; 2007.

42. Morris S, Devlin N, Parkin D, Spencer A. Economic Analysis in Healthcare. John Wiley \& Sons; 2012.

43. Marasinghe KM, Lapitan JM, Ross A. Assistive technologies for ageing populations in six lowincome and middle-income countries: a systematic review. BMJ Innov. 2015;1(4):182-195.

44. Matter R, Harniss M, Oderud T, Borg J, Eide AH. Assistive technology in resource-limited environments: a scoping review. Disabil Rehabil Assist Technol. 2017;12(2):105-114.

45. Instituto Nacional de Estadística y Censos. Incidencia de La Pobreza Y La Indigencia En 31 Aglomerados Urbanos. Ministerio de Hacienda https://www.indec.gob.ar/uploads/informesdeprensa/eph_pobreza_01_18.pdf. Accessed October 16, 2018.

46. Instituto Nacional de Estadística y Censos (INDEC). Estudio Nacional Sobre El Perl de Las Personas Con Discapacidad: Resultados Preliminares 2018. Ministerio de Hacienda; 2018. https://www.indec.gov.ar/ftp/cuadros/poblacion/estudio_discapacidad_07_18.pdf. Accessed October 16, 2018.

47. Ley 25.504 Sistema de Protección Integral de Los Discapacitados.; 2001. http://servicios.infoleg.gob.ar/infolegInternet/anexos/70000-74999/70726/norma.htm.

48. Constanza Rossi, Maria Natalia Basset, Norrna Samman. Estado nutricional de escolares y sus variables socioeconómicas. In: Encuentro Nacional de Nutricionistas AADYND. ; 2014. https://www.conicet.gov.ar/new_scp/detalle.php?keywords=\&id=34046\&congresos=yes\&detalles $=$ yes\&congr_id=2362348. Accessed October 16, 2018.

49. World Health Organization, UNESCO, International Labour Organization \& International Disability Development Consortium. Community-based rehabilitation: CBR guidelines. http://www.who.int/iris/handle/10665/44405.

50. Organization $\mathrm{WH}$, Others. Wheelchair service training package--Basic level. World Health Organization, Geneva, viewed. 2017;15.

51. Brazilian Institute of Geography and Statistics-IBGE, Brazill. 2010 Demographic Census General Characteristics of the Population, Religion and People with Disabilities.; 2010.

52. World Health Organization. Rehabilitation in Health Systems. Geneva; 2017.

53. Secretary for the Promotion of the Rights of Persons with Disabilities Brazil. Technical 
Assistance Committee - Assistive Technology.; 2009.

54. Ribeiro CTM, Ribeiro MG, Araújo AP, Mello LR, Rubim L da C, Ferreira JES. [The public health care system and rehabilitation actions in Brazil]. Rev Panam Salud Publica. 2010;28(1):43-48.

55. Censo Nacional de Población y Vivienda - Segunda entrega preliminar 2018. Departamento Administrativo Nacional de Estadística. https://sitios.dane.gov.co/cnpv-presentacion/src/. Published November 2, 2018. Accessed November 26, 2018.

56. World Bank. Colombia Country Profile. World Bank. http://databank.worldbank.org/data/views/reports/reportwidget.aspx?Report_Name=CountryProfil e\&ld=b450fd57\&tbar=y\&dd=y\&inf=n\&zm=n\&country=COL. Accessed October 1, 2018.

57. de Colombi G. Víctimas de Minas Antipersonal y Municiones sin Explosionar. Acción Contra Minas. http://www.accioncontraminas.gov.co/estadisticas/Paginas/victimas-minasantipersonal.aspx. Published August 31, 2018. Accessed October 1, 2018.

58. de la ONU para los Refugiados AA. Desplazamiento Forzado En 2017. United Nations; 2017. http://www.acnur.org/5b2956a04.pdf.

59. Censo Nacional de Población y Vivienda - Segunda entrega preliminar 2018. Departamento Administrativo Nacional de Estadística. https://sitios.dane.gov.co/cnpv-presentacion/src/. Published November 2, 2018. Accessed November 26, 2018.

60. Asamblea Nacional Constituyente. Constitución Política Colombiana (1991).; 6 de Julio de 1991.

61. Cifras de aseguramiento en salud. Ministerio de Salud y Protección Social. https://www.minsalud.gov.co/proteccionsocial/Paginas/cifras-aseguramiento-salud.aspx. Published October 1, 2018. Accessed August 2018.

62. Vélez AL. La acción de tutela: ¿un mecanismo de protección del derecho a la salud y un proceso alterno para acceder a servicios de salud? Colombia Médica. 2005;36(3). http://www.redalyc.org/html/283/28336311/.

63. de la Información y las Comunicaciones M de T. Centro de Relevo. Centro de Relevo. https://centroderelevo.gov.co/632/w3-channel.html. Accessed October 23, 2018.

64. Ley 1145 de 2007: Por Medio de La Cual Se Organiza El Sistema Nacional de Discapacidad Y Se Dictan Otras Disposiciones.; 2007. https://oig.cepal.org/sites/default/files/2007_ley1145_col.pdf.

65. Sentencia T-102.; 2007. http://www.corteconstitucional.gov.co/relatoria/2007/T-102-07.htm.

66. de Salud y Protección Social M. Política Pública Nacional de Discapacidad E Inclusión Social 2013-2022.; Diciembre de 2014.

https://www.minsalud.gov.co/sites/rid/Lists/BibliotecaDigital/RIDE/DE/PS/politica-publicadiscapacidad-2013-2022.pdf.

67. Consejo Nacional de Política Económica y Social. Conpes Social 166: Política Pública Nacional de Discapacidad E Inclusión Social.; 2013. https://colaboracion.dnp.gov.co/cdt/conpes/social/166.pdf.

68. LINEAMIENTOS NACIONALES DE REHABILITACIÓN BASADA EN LA COMUNIDAD - RBC. Ministerio de Salud; 2014. https://www.minsalud.gov.co/sites/rid/Lists/BibliotecaDigital/RIDE/VS/PP/ENT/lineamientosnacionales-rbc.pdf.

69. Cruz Velandia I, Fernández Moreno A, Duarte Cuervo C, García Ruíz S. Sistematización de Investigaciones En Discapacidad Y En La Estrategia de Rehabilitación Basada En Comunidad (RBC). Bogotá DC Período 2005-2010. Alcaldía Mayor de Bogotá; 2014.

http://repositoriocdpd.net:8080/handle/123456789/591. 
70. Ley 1680 de 2013: Por La Cual Se Garantiza a Las Personas Ciegas Y Con Baja Visión, El Acceso a La Información, a Las Comunicaciones, Al Conocimiento Y a Las Tecnologías de La Información Y de Las Comunicaciones. http://www.secretariasenado.gov.co/senado/basedoc/ley_1680_2013.html.

71. Inicio - ConVerTic. http://www.convertic.gov.co/641/w3-channel.html. Accessed August 23, 2018.

72. Resolución 5592 de 2015.; 2015:220.

https://www.minsalud.gov.co/Normatividad_Nuevo/Resoluci\%C3\%B3n\%205592\%20de\%202015 .pdf.

73. de Colombia C. Ley 1751 de 2015: Por Medio de La Cual Se Regula El Derecho Fundamental a La Salud Y Se Dictan Otras Disposiciones.; 2015.

https://www.minsalud.gov.co/Normatividad_Nuevo/Ley\%201751\%20de\%202015.pdf.

74. de Salud y Protección Social M. ABC de la Discapacidad. 2014.

https://www.minsalud.gov.co/sites/rid/Lists/BibliotecaDigital/RIDE/DE/PS/abece-de-ladiscapacidad.pdf.

75. Resolución 2968 de 2015: Por La Cual Se Establecen Los Requisitos Sanitarios Que Deben Cumplir Los Establecimientos Que Elaboran Y Adaptan Dispositivos Médicos Sobre Medida de Tecnología Ortopédica Externa Ubicados En El Territorio Nacional.; 2015:16.

http://biblioteca.saludcapital.gov.co/img_upload/03d591f205ab80e521292987c313699c/resolucio n-2968-de-2015.pdf.

76. de Salud y Protección Social M. Resolución 5267 de 2017.; 2017.

https://www.minsalud.gov.co/sites/rid/Lists/BibliotecaDigital/RIDE/DE/DIJ/resolucion-5267-de2017.pdf.

77. de Sanidad Militar DG. Protocolo Administrativo Para La Prescripción, Seguimiento Y Control de Los Productos de Apoyo En Salud Para EI SSFM. Ministerio de Defensa Nacional; 2015.

78. Resolución 350 de 2016: Por Medio de La Cual Se Reglamentan La Implementación de Los Sistemas de Acceso En Los Contenidos Transmitidos a Través Del Servicio Público de Televisión Que Garantizan El Acceso de Las Personas Con Discapacidad Auditiva Y Se Dictan Otras Disposiciones.; 2016.

https://www.icbf.gov.co/cargues/avance/docs/resolucion_antv_0350_2016.htm. Accessed October 24, 2018.

79. Decreto 1421 de 2017: Por El Cual Se Reglamenta En El Marco de La Educación Inclusiva La Atención Educativa a La Población Con Discapacidad.; 2017:20.

http://es.presidencia.gov.co/normativa/normativa/DECRETO\%201421\%20DEL\%2029\%20DE\%2 0AGOSTO\%20DE\%202017.pdf.

80. de Eudcación M. Guía Para La Implementación Del Decreto 1421 de 2017. Ministerio de Eudcación,; 2018.

http://aprende.colombiaaprende.edu.co/ckfinder/userfiles/files/Guia\%20de\%20apoyo\%20\%20Decreto\%201421\%20de\%202017\%2016022018\%20(1).pdf.

81. de Colombia G. Bienvenido a Biblioteca Virtual para Ciegos de Colombia | Biblioteca Virtual para Ciegos de Colombia. Instituto Nacional Para Ciegos INCl. http://biblioteca.inci.gov.co/. Accessed October 24, 2018.

82. Decreto 2011 de 2017.; 2017:4.

http://es.presidencia.gov.co/normativa/normativa/DECRETO\%202011\%20DEL\%2030\%20DE\%2 ONOVIEMBRE\%20DE\%202017.pdf.

83. Lucas Correa-Montoya JCR-SMV-I. \#EscuelaParaTodos: Panorama Y Retos Del Derecho a La Educación Inclusiva de Las Personas Con Discapacidad En Colombia. DescLAB; 2018. https://www.desclab.com/educacion-inclusiva. Accessed August 24, 2018. 
84. Rehabilitación física. Comité Internacional de la Cruz Roja. https://www.icrc.org/es/nuestrasactividades/salud/rehabilitacion-fisica. Accessed October 1, 2018.

85. Humanity and Inclusion Colombi. ¿Quiénes somos?

http://humanityandinclusioncolombia.com/quienes-somos/. Accessed October 1, 2018.

86. Concha FS. Proyecto TEAM: transformando vidas. Fundación Saldarriaga Concha. https://saldarriagaconcha.org/desarrollo_fsc/es/fsc-como-trabajamos/item/955-proyecto-teamtransformando-vidas. Published April 2018. Accessed October 24, 2018.

87. de las Personas con Discapacidad CCP la I de la CSLD. Informe Alternativo de La Coalición Colombiana Para La Implementación de La Convención Sobre Los Derechos de Las Personas Con Discapacidad.; Agosto 15 a Septiembre 2, 2016.

88. Correa Montoya, Lucas y Castro Martínez, Marta Catalina. Discapacidad E Inclusión Social En Colombia. Informe Alternativo de La Fundación Saldarriaga Concha Al Comité de Naciones Unidas Sobre Los Derechos de Las Personas Con Discapacidad. Editorial Fundación Saldarriaga Concha. ; 2016.

https://saldarriagaconcha.org/desarrollo_fsc/images/Informe_Alternativo_campa\%C3\%B1a.pdf.

89. Mishra S, DeMuth S, Sabharwal S, Watts HG, Lentz KKL, Huber M, Kembhavi G. Disability and rehabilitation in Tajikistan: development of a multisectoral national programme to leave no one behind. Panor Syntheses. 2018:202.

90. Ministry of Social Justice and Empowerment. ALIMCO Signed ToT Agreement with Motivation Charitable Trust of U.K to Manufacture WHO Compliant Wheelchairs in India 2016. Government of India

91. Hamner SR, Narayan VG, Donaldson KM. Designing for scale: development of the ReMotion Knee for global emerging markets. Ann Biomed Eng. 2013;41(9):1851-1859.

92. International Society of Wheelchair Professionals Policy Advocacy Toolkit. http://pak.wheelchairnetwork.org.

93. Frehywot S, Vovides $\mathrm{Y}$, Talib Z, Mikhail N, Ross H, Wohltjen H, Bedada S, Korhumel K, Koumare AK, Scott J. E-learning in medical education in resource constrained low- and middleincome countries. Hum Resour Health. 2013;11:4.

94. Liyanagunawardena TR, Aboshady OA. Massive open online courses: a resource for health education in developing countries. Glob Health Promot. January 2017:1757975916680970.

95. WHO | Priority Assistive Products List (APL). November 2017.

http://www.who.int/phi/implementation/assistive_technology/global_survey-apl/en/. Accessed September 4, 2018.

96. Wheelchair International Network - Training management system for the wheelchair sector. http://wheelchairnetwork.org/. Accessed September 4, 2018.

97. News \& Press. https://www.ispoint.org/page/Accreditation. Accessed September 4, 2018.

98. CECOPS. http://www.cecops.org.uk/. Accessed September 4, 2018.

99. Market Shaping Primer. https://www.usaid.gov/cii/market-shaping-primer. Accessed August 30, 2018.

100. Lin A, Wilson J. Healthy Markets for Global Health: A Market Shaping Primer. Washington, DC: Center for Accelerating Innovation and Impact, United States Agency for International Development; 2014. 2018.

101. Home. ATscale. https://atscale2030.org. Accessed August 30, 2018. 
102. Smith RO, Scherer MJ, Cooper R, Bell D, Hobbs DA, Pettersson C, Seymour N, Borg J, Johnson MJ, Lane JP, Sujatha S, Rao P, Obiedat QM, MacLachlan M, Bauer S. Assistive technology products: a position paper from the first global research, innovation, and education on assistive technology (GREAT) summit. Disabil Rehabil Assist Technol. 2018;13(5):473-485. 